1. MBBS, FCPS

\title{
Lactose intolerance in malnutrition: Do we guidelines?
}

Senior Registrar Paediatrics Medicine

Avicenna Medical College \& Hospital

Lahore.

2. MBBS, FCPS

Senior Registrar Paediatrics Medicine Indus Medical College \& Hospital Tando Muhammad Khan, Hyderabad.

3. MBBS, MCPS, FCPS

Associate Professor Paediatrics Medicine

Indus Medical College \& Hospital

Tando Muhammad Khan, Hyderabad.

4. MBBS, FCPS, CHPE

Assistant Professor Paediatrics Medicine

University of Lahore.

5. MBBS, FCPS

Senior Registrar Paediatrics Medicine Holy Family Hospital, Rawalpindi.

6. MBBS, FCPS

Senior Registrar Paediatrics Medicine

Mayo Hospital Lahore.

Correspondence Address:

Dr. Faraz Ahmed

Department of Paediatrics

Avicenna Medical College \& Hospita

Lahore.

faraz_ahmed55@hotmail.com

Article received on:

12/12/2019

Accepted for publication:

07/09/2020

Mohsin Ali ${ }^{1}$, Faraz Ahmed², Sikandar Ali Bhand ${ }^{3}$, Bilal Safdar ${ }^{4}$, Muhammad Hafeez $^{5}$, Muhammad Waqas 6

ABSTRACT... Objective: To determine the frequency of lactose intolerance in malnourished children presenting with acute watery diarrhea. Study Design: Cross Sectional study. Setting: Department of Pediatrics at The Children's Hospital \& the Institute of Child Health. Period: $20^{\text {th }}$ December 2015 till $20^{\text {th }}$ June 2016. Material \& Methods: A total of 225 children fulfilling inclusion criteria were selected. Stool samples were tested for reducing substances after informed consent from parents. Approval from Ethical Committee was taken. Data was entered and analyzed through SPSS 2.0. Results: Out of total 225 patients with age 3 months to 2 years (mean age $13.41 \pm 5.93$ months), $112(49.8 \%)$ were males and $113(50.2 \%)$ were females. Overall lactose intolerance was observed in $57(25.3 \%)$ patients, out of which, $27(24.1 \%)$ were males and $30(26.5 \%)$ were females. Total of $129(57.3 \%)$ had low socio-economic status out of which $35(27.1 \%)$ had lactose intolerance. Conclusion: In these malnourished children with acute watery diarrhea, lactose intolerance is high and local guidelines are necessary for proper screening and management.

Key words: $\quad$ Acute Watery Diarrhea, Malnourished, Lactose Intolerance.

Article Citation: Ali M, Ahmed F, Bhand SA, Safdar B, Hafeez M, Waqas M. Lactose intolerance in malnutrition: Do we guidelines? Professional Med J 2021; 28(4):564-567. https://doi.org/10.29309/TPMJ/2021.28.04.4411

\section{INTRODUCTION}

Lactose intolerance is one of causes of diarrhoea that can lead to treatment failure in children with malnutrition. ${ }^{1}$ So it is important that lactose intolerance should be identified as early as possible as change in diet can improve the outcome.

Lactose is converted into glucose and galactose by lactase enzyme which is present in enterocytes of small intestine. Deficiency of this enzyme leads to lactose intolerance as lactose is not absorbed. ${ }^{2,3}$

Lactose draws water into intestinal lumen by increasing osmolarity of intestine that leads to osmotic diarrhea, bloating, flatulence, abdominal distension, discomfort and perianal excoriation. Treatment options are; reduce or elimintate lactose from the diet or by lactase-enzyme replacement therapy. ${ }^{4-5}$ Lactose intolerance is of two types; primary and secondary. ${ }^{6}$ Congenital absence of enzyme activity in enterocytes of small intestine leads to primary intolerance. Inability to digest disaccharide lactose leads to secondary lactose intolerance. Causes of secondary lactose intolerance are; celiac disease, giardiasis, infectious enteritis, mucosal injury, bacterial overgrowth and drug induced enteritis. ${ }^{7-8}$

Malnutrition occurs when there is mismatch between body's nutrient requirements and intake. That results in deficiency of energy, protein, and micronutrients that can affects growth, development, and other relevant outcomes. ${ }^{9}$ Malnourished children commonly have low activity of intestinal lactase and feeding may result in retardation of nutritional recovery. Secondary lactose intolerance prevalence has been reported ranging from $26 \%$ to as high as $100 \%$ in affected children. ${ }^{10}$ Children with proteinenergy-malnutrition usually produce less lactase, and including this disaccharide interferes with recovery during nutritional rehabilitation. ${ }^{11-12}$

Rationale of our study is to determine lactose 
intolerance frequency in malnourished children presenting with acute watery diarrhea in our hospital so that we can have local estimate, applicable to local population and guidelines can be made for the management of malnourished children and prevent treatment failure in malnourished children.

\section{OBJECTIVE}

- To determine the frequency of lactose intolerance in malnourished children presenting with acute watery diarrhea in The Children's Hospital and The Institute of Child Health, Lahore.

\section{MATERIAL \& METHODS}

This cross-sectional study was conducted at the Pediatric Department of the Children's Hospital \& The Institute of Child Health, Lahore from: 20-12-2015 to 20-06-2016. It comprised of 225 children aged three months to two years, who met the WHO criteria of severe acute malnutrition (Z-score of <-3SD with weight for height/length, age and sex) presenting with diarrhoea. Children already on lactose free diets were excluded from the study. Children who fulfil selection criteria were enrolled in the study after taking informed consent from parents. A sample of $5 \mathrm{ml}$ of stool from liquid portion was taken into container and sent for testing of reducing substances in laboratory of the hospital. Results were received and analysed. Reports were discussed with consultant and lactose intolerance was labelled as per operational definition. All this information was recorded through proforma (attached). Malnutrition and lactose intolerance were managed as per hospital protocol. Approval from Ethical Committee was taken. Data was entered and analysed through SPSS 20. Mean and standard deviation were calculated for quantitative variables like age, height \& weight. Frequency and percentage were calculated for qualitative variables like gender and presence of lactose intolerance. Data was stratified for age, gender and socio-economic status to deal with effect modifiers. Post-stratification Chi-square test was applied. P-value $<0.05$ was considered significant.

\section{Operational Definition}

\section{Acute Severe Malnutrition}

Malnutrition of less than 3months duration with $\mathrm{WHO}$ weight for length/height Z-score $<-3{ }^{13}$

\section{Secondary Lactose Intolerance}

A child who was previously normal since birth, who develops diarrhea with signs and symptoms of lactose intolerance (diarrhea, abdominal distension, and perianal excoriation) and positive stool for reducing substances later in life.

\section{Diarrhea}

Defined as the passage of three or more than three loose watery tools per day. ${ }^{14}$

\section{Inclusion Criteria}

1. Acute watery diarrhea

2. Age 3 months to 2 years

3. Malnourished children

\section{Exclusion Criteria}

1. Dysentery

2. Co-morbid conditions like celiac disease, $\mathrm{CHD}$

3. Age $<3$ months and $>2$ years

\section{RESULTS}

Out of 225 cases aged 3 months to 2 years, $112(49.8 \%)$ were males and $113(50.2 \%)$ were females. Mean age was $13.41 \pm 5.93$ months. Overall lactose intolerance (who had diarrhea and positive reducing substance) was found in $57(25.3 \%)$ patients, whereas it was negative in $168(74.7 \%)$ patients. The mean stool $\mathrm{pH}$ value of 225 patients in this study was noted as $5.86 \pm 1.03$ with minimum and maximum values of $3.4 \& 7.5$ respectively. Among 112 male cases, 27 (24.1\%) had lactose intolerance while 85 (75.9\%) did not. While out of 113 female cases, 30 (26.5\%) were positive for lactose intolerance and 83 (73.4\%) were not lactose intolerant. Total of 129 (57.3\%) had low socio-economic status out of which 35 $(27.1 \%)$ had lactose intolerance The difference was insignificant $(P>0.05)$. 


\begin{tabular}{|c|c|c|c|c|c|c|c|}
\hline & & \multicolumn{4}{|c|}{ Sex } & \multirow{2}{*}{\multicolumn{2}{|c|}{ Total }} \\
\hline & & \multicolumn{2}{|c|}{ Male } & \multicolumn{2}{|c|}{ Female } & & \\
\hline \multirow{2}{*}{$\begin{array}{l}\text { Lactose } \\
\text { Intolerance }\end{array}$} & Yes & \multicolumn{2}{|c|}{$27(24.1 \%)$} & \multicolumn{2}{|c|}{$30(26.5 \%)$} & \multicolumn{2}{|c|}{$57(25.3 \%)$} \\
\hline & No & \multicolumn{2}{|c|}{$85(75.9 \%)$} & \multicolumn{2}{|c|}{$83(73.4 \%)$} & \multicolumn{2}{|c|}{$168(74.7 \%)$} \\
\hline \multicolumn{2}{|l|}{ Total } & \multicolumn{2}{|c|}{$112(49.8 \%)$} & \multicolumn{2}{|c|}{$113(50.2 \%)$} & \multicolumn{2}{|c|}{$225(100 \%)$} \\
\hline \multicolumn{8}{|c|}{$\begin{array}{l}\text { Table-I. Comparison of lactose intolerance between } \\
\text { both genders } \\
\text { Chi Value }=0.177, \text { p-value }=0.674 \text { (Insignificant) }\end{array}$} \\
\hline & & & & \multicolumn{3}{|c|}{$\begin{array}{l}\text { Reducing } \\
\text { substance }\end{array}$} & \multirow[t]{2}{*}{ Total } \\
\hline & & & & Yes & & No & \\
\hline \multirow{3}{*}{$\begin{array}{l}\text { Age } \\
\text { recorded }\end{array}$} & \multicolumn{3}{|c|}{3 to 12 months } & 32 & & 11 & 143 \\
\hline & \multicolumn{3}{|c|}{13 to 24 months } & 25 & & 57 & 82 \\
\hline & \multicolumn{3}{|c|}{ Total } & 57 & & 68 & 225 \\
\hline \multicolumn{8}{|c|}{ Table-II. Age recorded reducing substance } \\
\hline & & & \multicolumn{2}{|c|}{ Yes } & \multicolumn{2}{|c|}{ No } & Total \\
\hline \multicolumn{3}{|c|}{ Abdominal distension } & \multicolumn{2}{|c|}{$43(75.4 \%)$} & \multicolumn{2}{|c|}{$14(24.6 \%)$} & 57 \\
\hline \multicolumn{3}{|c|}{ Perianal excoriation } & \multicolumn{2}{|c|}{$38(66.6 \%)$} & \multicolumn{2}{|c|}{$19(33.3 \%)$} & 57 \\
\hline
\end{tabular}

\section{DISCUSSION}

Severe malnutrition is often complicated by diarrhea. In 2013, it was estimated that 2 million deaths occur annually due to diarrhea and ${ }^{15}$ almost 1.7 billion cases are reported each year that kills around 760,000 children under five. More than half of these were in Africa and South Asia. Diarrhea is the second leading cause of mortality (16\%) in children under five. In 2008, nearly 465,000 child deaths occur in Pakistan due to diarrhea. Pakistan is fourth in number that is contributing $5 \%$ ( 1 in every 20 child deaths) to the child mortality pie. ${ }^{16}$

In our study, Lactose intolerance incidence was almost same that is $57(25.33 \%)$ as in Senegalese study and Z. A Bhutta study held in Karachi 26 $\%$ and (25\%) 24 respectively however it was lower than other studies report. ${ }^{17-19}$

In our study secondary lactose intolerance was $56.1 \%$ in infantile age group (3-12 months), while in Nyeko et al study at Mulago it was $68 \% .^{20}$

Mira Verma described lactose intolerance in 40 children suffering from protein energy malnutrition and 10 control children. Two cases of kwashiorkor show evidence of lactose intolerance by a flat curve, diarrhea, low stool $\mathrm{pH}$, and positive reducing substances in stools. Four out of 38 marasmus children shows no signs of intolerance except maximum blood sugar rise below 20-30 $\mathrm{mg} / \mathrm{dl}^{21}$

Perianal rash ( $p$ value 0.00 ) and abdominal distention ( $p$ value, 0.00 ) are more common in children with secondary lactose intolerance. Lactose that is not metabolized is a nutritive source for intestinal bacteria (especially large bowel). Lactose metabolism by bacteria results in formation of volatile fatty acids and gases (carbon dioxide, methane and hydrogen), leading to flatulence. The fatty acids decrease stool $\mathrm{pH}$, causing excoriation and rash on contact with perianal region. With significant intestinal gas by the intestinal bacteria, abdominal distention occurs.

Our study results showed the mean age of the children with diarrhea as $13.41 \pm 5.93$ months, while study done by Molbak $\mathrm{K}$ et al and Woldemicael $G$, shows highest rates in children of 6-11 months age and it decreases as children grows old. $22-23$

Our study findings are primary in local targeted population, and it needs some-other studies to validate our findings.

\section{CONCLUSION}

It was concluded that the rate of lactose intolerance is high among malnourished. Its clinical signs in severely malnourished children included perianal skin rash and abdominal distention and positive stool examination for reducing substances. It is common in infantile age group. Local guidelines are required for proper screening and management of patients with acute watery diarrhea, also having malnutrition.

\section{ACKNOWLEDGEMENT}

No financial support or remuneration was received for this study.

Copyright@ 07 Sep, 2020.

\section{REFERENCES}

1. Campbell AK, Waud JP, Matthews SB. The molecular basis of lactose intolerance. Sci Prog. 2009; 92:241- 87. 
2. Buller HA, Grand RJ. Lactose intolerance. Ann Rev Med 2003; 41: 141-8.

3. Maiuri L, Raia V, Potter J. Mosaic pattern of lactase expression by villus enterocytes in human adult-type hypolactasia. Gastroenterology 2002; 100: 359-69.

4. Euroasian J Hepatogastroenterol. 2016 Jan-Jun; 6(1): 5-7. Published online 2016 Jul 9. doi: 10.5005/jpjournals-10018-1156.

5. Heyman, M., 2006. Lactose Intolerance in Infants, Children, and Adolescents. PEDIATRICS, [online] 118(3), pp.1279-1286. Available at: http://www. pediatrics.org/cgi/doi/10.1542/ peds.2006-1721.

6. Kirschner BS, DeFavaro MV, Jensen W. Lactose malabsorption in children and adolescents with inflammatory bowel diseases. Gastroenterology 2002; 81: 829-32.

7. Wedlake L, Thomas K, McGough M. Small bowel bacterial overgrowth and lactose intolerance during radical pelvic radiotherapy. Eur $\mathrm{J}$ Cancer 2008; 44: 2212-7.

8. Ghoshal UC, Ghoshal U, Misro A, Choudhuri G. Partially responsive celiac disease resulting from small intestinal bacterial overgrowth and lactose intolerance. BMC Gastroenterol 2004; 4: 10.

9. Mehta NM, Corkins MR, Lyman B, et al; and the American Society for Parenteral and Enteral Nutrition [A.S.P.E.N.] Board of Directors. Defining pediatric malnutrition: A paradigm shift toward etiology-related definitions. J Parenter Enteral Nutr. 2013; 37:460-481.

10. UNICEF Data: Monitoring the Situation of Children and Women 2016 [cited 2016]; Available from: http:// data.unicef.org/child-health/diarrhoeal-disease.html.

11. Euroasian J Hepatogastroenterol. 2016 Jan-Jun; 6(1): 5-7. Published online 2016 Jul 9. doi: 10.5005/jpjournals-10018-1156.

12. UNICEF Data: Monitoring the Situation of Children and Women 2016 [cited 2016]; Available from: http:// data.unicef.org/child-health/diarrhoeal-disease.html.
13. http://www.who.int/nutgrowthdb/about/introduction/ en/index4.html.

14. Guarino A. Chronic diarrhoea. In: Stanton K. Nelson texbook. 19th ed. USA: Fletcher J; 2011.p.1339.

15. UNICEF Data: Monitoring the Situation of Children and Women 2016 [cited 2016]; Available from: http:// data.unicef.org/child-health/diarrhoeal-disease.html.

16. UNICEF. Pakistan Statistics. [Online]. 2013. [Cited 2016]. Available from: http:// www.unicef.org/ infobycountry/pakistan_pakistan_statistics.html.

17. Beau JP, Fontaine O, Garenne M: Management of malnourished children with acute diarrhoea and sugar intolerance. J Trop Pediatr 1989, 35(6):281-4.

18. Bhutta, Z.A. Nizami S.Q. Lactose intolerance in persistent diarrhoea during childhood. Comparison of a traditional rice-lentil based diet with soy formula. Pediatrics, 1991; 88:1010-20-24.

19. Fagundes-Neto $U$, Viaro T, Lifshitz F: Tolerance to glucose polymers inmalnourished infants with diarrhoea and disaccharide intolerance. AmJ Clin Nutr 1985, $41(2): 228-34$.

20. Nyeko et al., Lactose intolerance among severely malnourishedchildren with diarrhoea admitted to the nutrition unit, Mulagohospital, Uganda BMC Pediatrics 2010, 10:31.

21. Verma M. \& Saxena S. Lactose intolerance in children with protein-energy malnutrition. Indian $\mathrm{J}$ Pediat, 1980, 47(4): 273-277.

22. Molbak K, Gerner-Smidt P, Wegener HC. Increasing quinolone resistance in Salmonella enterica serotype Enteritidis. Emerg Infect Dis.2002, 8 (5):514-515.

23. Woldemicael G. Diarrhoeal Morbidity among Young Children in Eritrea: Environmental and Socioeconomic Determinants. J Health Popul Nutr. 2001, 19(2):83-90.

\section{AUTHORSHIP AND CONTRIBUTION DECLARATION}

\begin{tabular}{|c|l|l|l|}
\hline Sr. \# & \multicolumn{1}{|c|}{ Author(s) Full Name } & \multicolumn{1}{|c|}{ Contribution to the paper } & Author(s) Signature \\
\hline 1 & Mohsin Ali & Author & Suy \\
2 & Faraz Ahmed & Author & Co-Author \\
3 & Sikandar Ali Bhand & Co-Author \\
4 & Bilal Safdar & Co-Author & \\
5 & Muhammad Hafeez & Co-Author & \\
6 & Muhammad Waqas & Co-
\end{tabular}

